\title{
Human and social capital facing challenges of economic convergence processes in Poland
}

\section{Introduction}

Economic convergence is a category that carries a positive connotation, indicating that there is a possibility of bridging the growth disparities in socio-economic space. In the real economy, however, the phenomenon of economic convergence is rare (Prichett 1997). The dynamics of growth processes and socio-economic development is contextual; it depends on a combination of many mutually interacting economic and socio-political factors (as emphasized in endogenous growth theories or the concept of conditional convergence) (Romer 1986; Barro 1992; 1996; Dowrick 2003).

Moreover, debates on the driving forces of development are continually being enriched with new lines of research. New development factors are sought, as those identified by our predecessors have proven to be insufficient over time. Simultaneously, there has been a shift in the theoretical approach as to the importance and strength of the impact of these factors. In the knowledge-based economy, the focus is gradually shifting from quantitative and tangible factors to qualitative and intangible ones (and this set is also being broadened by social factors). The importance of the institutional settings of development and social capital standing on the verge of social and economic dimension are highlighted. In conjunction with this, research on the multidimensional structure of intangible forms of capital (human capital, social capital) is on the increase, as are studies regarding the importance of two-way interactions between these capitals in boosting the efficiency of business processes (Czapiński 2008; Dinda 2008, 2014; Piazza-Georgi 2002; Schuller 2000; Kaasa and Parts 2008; Miguélez, et al., 2009). At the same time, the discussion around the phenomenon of real convergence

\footnotetext{
* University of Rzeszow, Faculty of Economics, Microeconomics Department, e-mail: mwosiek@ ur.edu.pl
} 
gradually goes beyond the scope of the theory of economic growth, often involving issues of development and economic prosperity.

In economic debates, the way we approach human capital is also changing. It presents a more-humanistic feature, taking into account various aspects of its presence in economic processes as well as the empathy towards the social environment in which it operates. Human capital is activated in action processes, where the support functions of social capital (i.e., willingness of business entities to cooperate and coordinate activities) are manifest. Relationships between human and social capitals are complementary; that is to say, the economic effects of human capital can be enhanced if it functions in an environment with a strong social capital (of an appropriate structure). This is confirmed by the results of pilot studies indicating that the impact of human capital on economic development and innovative activity is stronger in societies with greater social capital (Kaasa and Parts 2008, p. 30; Miguélez et al. 2009, p. 19-24).

The importance of intangible factors in generating differences in development is not the same in time and space. Benefits arising from individual knowledge (human capital) and the willingness of business entities to cooperate (social capital) ${ }^{1}$ may materialize if the traditional factors and conditions of development in the form of physical capital are provided. Furthermore, the impact of intangible resources increases with the transition of an economy to higher stages of development. The impact of intangible forms of capital on shaping the trajectory of development processes can, thus, indirectly indicate the maturity level of the structures and economic processes in a given area.

The endogenization of the development factors means that the conditions in which they operate and accumulate do matter. Depending on this, correlations between them can lead to either divergence or convergence. Investment in human capital and knowledge is not necessarily subject to the law of diminishing marginal returns, which gives raise to poorer areas catching up with their richer counterparts (Ortigueira and Santos 1997). Under the findings of the new economic geography, the mechanisms responsible for the polarization extend to the processes of spatial concentration of the production factors and economic

\footnotetext{
${ }^{1}$ This is only one of the possible ways of understanding the social capital that concerns economic organizations/enterprises. The notion of social capital has a very broad meaning - it is considered as an indispensable determinant for the stable and efficient functioning of a democratic political system and market economy: a) in the economic dimension, it can be interpreted metaphorically as a kind of binding agent, a factor integrating the other, material and non-material forms of capital; b) in the public sphere, social capital coordinates individual and collective actions, allowing "participants to act together more effectively to pursue shared objectives" (Putnam, 1995, p. 664-665), determining the scale of citizens' involvement and complementing the deficiencies of formal institutions.
} 
activity in growth centers; e.g., metropolitan areas (Krugman 1991; Gorzelak 2008). From economic debates emerges an ambiguous role of human capital in the processes of economic convergence. Depending on the assumptions being made (neoclassical versus endogenous growth theory) and operating conditions (practice), it can either increase or decrease the chances of economic convergence (Jabłoński 2012). Human capital boosts the growth of the areas that are able to take advantage of this attribute.

In this context, the challenge as far as the processes of economic convergence are concerned is to identify the key development factors for a given area, ensure their appropriate level and structure, and create operating conditions that enable them to increase the chance of bridging the income gap. The aggravation of uneven development is likely to have significant social and economic costs. This leads to the incomplete or inadequate use of the production potential of peripheral areas; and in the long term, it disrupts the allocation of resources throughout the economic system. The outlined challenge also remains valid for the Polish economy, where the differences in living standards have built up between regions basically from the beginning of the transformation period.

Considering the rationale, the subject matter explored in this study is the role of human and social capital in shaping the processes of regional development in Poland. The study is aimed at seeking answers to the questions of whether and to what extent the characteristics of human and social capital development impeded or fostered the achievement of convergence in the living standards (GDP per capita) in regional systems (NUTS-2). The reflections are based on a data analysis of the Polish Central Statistical Office (GUS) and periodic panel studies "The Social Diagnosis." The following tools were used: a multidimensional statistical exploratory analysis - a cluster analysis (Ward's, k-means); linear ordering - as well as a correlation analysis; and measures of statistical dispersion. Given the availability of data describing the social capital in the regions, the analysis covered the years period of 2002-2014².

\section{Methodology}

Research addressing the issue of economic convergence usually starts by determining whether $\beta$-convergence occurs, implying that areas with lower GDP per capita show a faster rate of change of this measure (Kusidel 2013, p. 74). The fundamental verification tools are econometric models estimating the equa-

\footnotetext{
${ }^{2}$ Due to editorial requirements, only the results of analysis from the first and last years of this period
} are depicted. 
tion under the assumptions of the neoclassical model of growth (Dańska-Borsiak 2011, p. 194):

$$
\ln \left(y_{j, t}\right)=\alpha_{0}+(\gamma+1) \ln \left(y_{j, t-1}\right)+\theta^{T} X_{j, t}+\left(\alpha_{j}+\varepsilon_{j, t}\right)
$$

where:

$$
\begin{aligned}
y_{j, t} & - \text { GDP per capita (in constant prices) of region } j \text { at time } t, \\
X_{j, t} & - \text { vector of explanatory variables, } \\
\alpha_{0}, \gamma, \theta & - \text { regression coefficients } \\
\alpha_{j} & - \text { fixed-region effects } \\
\mu_{t} & - \text { fixed (annual) time effects } \\
\varepsilon_{j, t} & - \text { error term of the specification. }
\end{aligned}
$$

Through different estimation methods and considering a different set of explanatory variables, the estimation results of the above-mentioned equation shown in numerous studies devoted to regional development in Poland (DańskaBorsiak 2011, p. 200-201, Wójcik 2008; Kusideł 2013; Kliber 2007; 2011; Gajewski, Tokarski 2004; Bal-Domańska 2014; Kosmalski 2016) - indicate a growing income gap between the richer and poorer regions of Poland. These studies also demonstrate the likelihood of the so-called club convergence occurring in Poland; i.e., the reduction of growth disparities in narrower clusters (clubs) of regions that are more homogeneous due to their structural characteristics.

Regarding Poland, however, econometric tools are of limited use in verifying the hypothesis of the occurrence of the club convergence due to the small number of regions within clubs (Dańska-Borsiak 2011, p. 202). For preliminary determination of whether Polish regions can create the so-called convergence clubs in the current study, exploratory data analysis tools were used (such as a cluster analysis) with the aim of identifying the most-homogeneous clusters of regions according to pre-set parameters. The grouping was based on the variables used in the basic version of the conditional $\beta$-convergence equation: GDP per capita, capital expenditure per employee (expressed in constant prices from the year 2000), and population growth rate. Ward's method and the k-means method were used.

To answer the question of whether the changes in GDP per capita in regions were related to human and social capital after 2002 (and if so, to what extent), indicators were selected to diagnose the condition of both capitals (Tab. 1).

The operationalization of human capital was based on the definition stemming from the reflections by T.W. Schultz (1961) and G.S. Becker (1975), according to which (in broad terms) human capital includes knowledge, skills, health, and vital energy, which are the carriers of a person, society, or nation (Domański 1993, p. 10). Two fundamental dimensions of this capital were distinguished: knowledge and skills as well as health. The operationalization of social capital 
Human and social capital facing challenges of economic convergence...

was based on the concept by R. Putnam (1995) and F. Fukuyama (1997), according to which social capital is embedded in the quantity and quality of social relations; its structure is subdivided into three dimensions: normative (trust and social norms), behavioral (active citizenship), and structural (formal and informal networks functioning in society ${ }^{3}$ ).

Table 1

Analytical indicators of human capital and social capital

\begin{tabular}{|c|c|c|}
\hline Variable & Statistical indicators evaluating human/social capital & $\begin{array}{l}\text { Variables' } \\
\text { character }\end{array}$ \\
\hline \multicolumn{3}{|c|}{ Human capital components } \\
\hline \multicolumn{3}{|c|}{ Knowledge and skills } \\
\hline $\mathrm{hc}_{1}$ & $\begin{array}{l}\text { Percentage of population aged } 15 \text { or above with tertiary level } \\
\text { of educational attainment }\end{array}$ & $\mathrm{S}$ \\
\hline $\mathrm{hc}_{2}$ & $\begin{array}{l}\text { Percentage of population aged } 15 \text { or above with lower sec- } \\
\text { ondary, primary, and lower levels of educational attainment }\end{array}$ & $\mathrm{D}$ \\
\hline $\mathrm{hc}_{3}$ & $\begin{array}{l}\text { Entrepreneurship - people conducting economic activity per } \\
1000 \text { population }\end{array}$ & S \\
\hline \multicolumn{3}{|c|}{ Health } \\
\hline $\mathrm{hc}_{4}$ & Life expectancy at birth (male) & $\mathrm{S}$ \\
\hline $\mathrm{hc}_{5}$ & Infant deaths per 1000 live births & $\mathrm{D}$ \\
\hline $\mathrm{hc}_{6}$ & The rate of natural increase $\left.{ }^{a}\right)$ & $\mathrm{S}$ \\
\hline $\mathrm{hc}_{7}$ & $\begin{array}{l}\text { Demographic dependency ratio - post-working age popula- } \\
\text { tion per } 100 \text { population of working age }\end{array}$ & $\mathrm{D}$ \\
\hline \multicolumn{3}{|c|}{$\begin{array}{l}\text { Social capital components } \\
\end{array}$} \\
\hline \multicolumn{3}{|c|}{ Normative (trust and social norms) } \\
\hline $\mathrm{sc}_{1}$ & $\begin{array}{l}\text { Level of generalized trust - most people can be trusted (per- } \\
\text { centage of respondents) }\end{array}$ & $\mathrm{S}$ \\
\hline \multicolumn{3}{|c|}{ Behavioral (active citizenship) } \\
\hline $\mathrm{sc}_{2}$ & $\begin{array}{l}\text { Activity on behalf of local community (percentage of respon- } \\
\text { dents) }\end{array}$ & $\mathrm{S}$ \\
\hline $\mathrm{sc}_{3}$ & Participation in public meetings (percentage of respondents) & $\mathrm{S}$ \\
\hline
\end{tabular}

3 Indicators describing informal social networks (circle of friends, frequency of meetings with friends, satisfaction from relationships with those closest to them as well as their colleagues) were characterized by a low variability. Therefore, this dimension was not included in the structural construct of the social capital (Table 1). 
Table 1 cont.

\begin{tabular}{|l|l|c|}
\hline Variable & \multicolumn{1}{|c|}{ Statistical indicators evaluating human/social capital } & $\begin{array}{c}\text { Variables' } \\
\text { character }\end{array}$ \\
\hline $\mathrm{sc}_{4}$ & Crimes ascertained by the Police per 1000 population & $\mathrm{D}$ \\
\hline $\mathrm{sc}_{5}$ & $\begin{array}{l}\text { Positive attitude towards democracy (percentage of respon- } \\
\text { dents) }\end{array}$ & $\mathrm{S}$ \\
\hline \multicolumn{2}{|c|}{ Structural (formal networks) } \\
\hline $\mathrm{sc}_{6}$ & Participation in associations (percentage of respondents) & $\mathrm{S}$ \\
\hline $\mathrm{sc}_{7}$ & $\begin{array}{l}\text { Active exercise of functions in organizations (percentage of } \\
\text { respondents) }\end{array}$ & $\mathrm{S}$ \\
\hline $\mathrm{sc}_{8}$ & $\begin{array}{l}\text { Performance of public administration institutions - "You have } \\
\text { had to use connections or other ways to deal with some for- } \\
\text { mal matter" - percentage of respondents claiming "often" }\end{array}$ & $\mathrm{D}$ \\
\hline
\end{tabular}

S - stimulant; D - destimulant.

a) In order for the used diagnostic variables to have a positive value on the construction of the taxonomical measure of human capital, the rate of natural increase for each region and each year was increased by a constant $(a=3)$.

\section{Source: own study}

Cluster analyses (Ward's method, k-means method) were used to seek answers to the following questions:

- Do similarities of regions in terms of human capital coincide with the ones specific to social capital?

- Are there similarities between the clustering of regions by traditional factors of economic development and their possession of human and social capital?

The Pearson coefficients of correlation between the variables of human and social capital and the level and changes in GDP per capita were also calculated. On this basis, conclusions were made regarding the cohesion in the development of human and social capital in regional space in Poland and their relationship to economic development.

In accordance with the theoretical prerequisites, the nature of the variables from Table 1 was determined as follows. As far as stimulants are concerned, higher values of variables contribute to the increase of human and social capital, whereas for destimulants, the direction of impact is reverse. In order to harmonize the nature of the variables, destimulants were transformed into stimulants by inverting the values of the characteristics (Młodak 2006, p. 34). The ability of discriminatory variables was verified by adopting a critical value of the coefficient 
of variation of $10 \%^{4}$ and a Pearson correlation coefficient of 0.85 . The variables were normalized to ensure their comparability (Strahl 2006, p. 163):

where:

$$
z_{i j, t}=\frac{x_{i j, t}}{\max _{j=1,2 \ldots 16, t}\left[x_{i j, t}\right]}
$$

$x_{i j, t}$ - shall mean the value of $i$ stimulant in $j$ region in $t$ year,

$z_{i j t}$ - the values of the standardized stimulants.

As a basis for normalization, the maximum value of $i$ in the group of all regions throughout the considered period was used. The advantage of the presented formula is that the transformed variables retain the primary level of variability. In addition, the values of $z_{i j}$ are normalized in interval $[0,1]$ and may be compared inter-periodically.

To get an overall picture of the deployment of human and social capital in the regional space, a synthetic measure of human and social capital was calculated for each region (Strahl 2006, p. 166):

$$
\mu_{j, t}=\frac{1}{m} \sum_{i=1}^{m} z_{i j t}
$$

Values of the measures belong to interval $[0,1]$, and higher values indicate a higher human or social capital.

\section{Economic polarization of Polish regions}

The results of clustering regions by capital expenditure per employee, rate of population growth, and GDP per capita (Tab. 2) as well as the measures of differentiation confirm previous findings that, in the processes of regional development in Poland from 2002 through 2014, divergence processes prevailed over the convergence ones. The value of the variation coefficient (for GDP per capita) based on the standard deviation $\left(V_{s}\right)$ increased from 0.211 in 2002 to 0.252 in 2014; for the coefficient using the quartile deviation $\left(V_{Q}\right)$, it increased from 0.126 in 2002 to 0.145 in 2014 . The distances between the clusters of similar regions (measured in the Euclidean setting) increased further as well. The furthest distance was between the Mazovia region and the eastern ones - in 2002, this amounted to 12,470, and in $2014-14,270$. At the same time, the distance between the Mazovia and Cluster

\footnotetext{
${ }^{4}$ The variable describing the life expectancy presented a low variability (coefficient of variation ranged between 0.01 and 0.02 ), and after 2006, so did the natural increase rate (the value of the coefficient of variation was about 0.08 ).
} 
No. 3 continued to expand (from 10,740 to 11,711), whereas between Mazovia and Cluster No. 2, it remained at a similar level (8310 as opposed to $831^{5}$ ). By comparison, the distances between Clusters No. 2, 3, and 4 were smaller (from 2430 to 6004 ), but they also increased during the period considered.

Table 2

Clustering of regions by traditional factors of economic development ${ }^{5}$

\begin{tabular}{|c|c|c|c|c|c|}
\hline \multirow{2}{*}{$\begin{array}{c}\text { Cluster } \\
\text { No. }\end{array}$} & \multicolumn{2}{|c|}{2002} & \multicolumn{3}{|c|}{2014} \\
\hline & Regions & $\begin{array}{c}\text { GDP } p c[\text { PLN }] \\
V_{s}\end{array}$ & Regions & \multicolumn{2}{|c|}{$\begin{array}{c}\text { GDP pc [PLN] } \\
V_{s}\end{array}$} \\
\hline 1 & Mazovia & $\begin{array}{c}31,095 \\
-\end{array}$ & Mazovia & \multicolumn{2}{|c|}{$\begin{array}{c}43,666 \\
-\end{array}$} \\
\hline 2 & $\begin{array}{l}\text { Lower Silesia, } \\
\text { Pomerania, } \\
\text { Wielkopolskie, } \\
\text { Silesia }\end{array}$ & $\begin{array}{c}21,371 \\
0.034\end{array}$ & $\begin{array}{l}\text { Lower Silesia, Wiel- } \\
\text { kopolskie, Silesia, } \\
\text { Pomerania }\end{array}$ & $\begin{array}{c}28,549 \\
0.068\end{array}$ & $\begin{array}{c}29,417^{*} \\
0.036 *\end{array}$ \\
\hline 3 & $\begin{array}{l}\text { Kujawy-Pome- } \\
\text { rania, Lodzkie, } \\
\text { Lubusz, Malo- } \\
\text { polskie, West } \\
\text { Pomerania }\end{array}$ & $\begin{array}{c}18,625 \\
0.033\end{array}$ & $\begin{array}{l}\text { Kujawy-Pomerania, } \\
\text { Opolskie, Lubusz, } \\
\text { West Pomerania, } \\
\text { Lodzkie, Malopol- } \\
\text { skie, Podkarpackie, } \\
\text { Podlaskie }\end{array}$ & $\begin{array}{c}22,438 \\
0.10\end{array}$ & $\begin{array}{c}23,988 * * \\
0.064 * *\end{array}$ \\
\hline 4 & $\begin{array}{l}\text { Lubelskie, } \\
\text { Opolskie, } \\
\text { Swietokrzyskie, } \\
\text { Podkarpackie, } \\
\text { Podlaskie, } \\
\text { Warmia-Masuria }\end{array}$ & $\begin{array}{c}15,703 \\
0.044\end{array}$ & $\begin{array}{l}\text { Warmia-Masuria, } \\
\text { Lubelskie, } \\
\text { Swietokrzyskie }\end{array}$ & $\begin{array}{c}19,519 \\
0.022\end{array}$ & $\begin{array}{l}19,528 * * * \\
0.0183^{* * * *}\end{array}$ \\
\hline \multicolumn{2}{|c|}{16 regions } & $\begin{array}{l}V_{s}=0.211 \\
V_{Q}=0.126\end{array}$ & 16 regions & \multicolumn{2}{|c|}{$\begin{array}{l}V_{s}=0.252 \\
V_{O}=0.145\end{array}$} \\
\hline
\end{tabular}

$p c$ - per capita; $V_{s}$ - standard deviation, $V_{Q}$ - quartile deviation.

* without Pomerania, ** including Pomerania, without Podkarpackie and Podlaskie, *** including Podkarpackie, Podlaskie

Source: own calculations based on Polish Central Statistical Office data - https://bdl.stat.gov.pl/ BDLS/metadane

\footnotetext{
${ }^{5}$ The clustering of regions was conducted on the basis of standardized variables. The analysis of variance showed that, among the adopted variables, the population growth rate is not statistically significant in determining the affiliation of regions to their respective clusters. The cluster analysis was also performed using the original data. In 2002 in both variants of the clustering, a similar composition of clusters was obtained, whereas in 2014, differences in the classification of regions were recorded. In Table 1, symbol $*$ indicates the results of the cluster analysis performed on the basis of the original data.
} 
In the following years, the distinctness of Mazovia could clearly be seen, as this one-element set was better equipped with traditional production factors (as compared to the rest of the country). Other regions formed three distinct clusters with a relatively stable composition. The cluster including the western regions (Lower Silesia, Wielkopolskie, Silesia) stood out due to their developed urban agglomerations (Wroclaw, Poznan, Katowice). In comparison to the rest of the country, the uniqueness of the eastern regions (Lubelskie, Podkarpackie, Podlaskie, Swietokrzyskie, Warmia-Masuria) generally classified into one cluster; and the fact that they were least-equipped in the traditional factors of economic development was also noticeable.

Exploratory cluster analysis revealed a pattern involving the creation of groups of similar regions that increasingly drifted apart over the subsequent years. At the same time, diverging trends can be observed within each cluster. During the analyzed period, the level of uneven development decreased among the eastern regions, remained the same among the western ones, and increased among those from Cluster No. 3.

The observed regularities indicate the possibility of the club convergence phenomenon occurring in Poland. They outline the two clubs created by the western regions (metropolitan) and the eastern ones. It should be taken into account that the multidimensional exploratory analysis tools used are not sufficient to confirm such a convergence; they only show certain symptoms of such a regularity. Nevertheless, the findings presented are partly consistent with the conclusions of P. Kliber (2011, p. 5), who distinguished two convergence clubs in the spatial development of Poland: the western regions and the regions with metropolitan areas. On the other hand, E. Kusidel (2013, p. 132) indicated that convergence clubs are created due to the prosperity of the regions, and Mazovia strives to attain a separate (higher) level of growth path.

\section{Human and social capital versus regional diversity}

In $2002-2014^{6}$, Polish regions were increasingly equipped in human and social capital, as testified by the growing values of the aggregate measures as well as the majority of analytical indicators of these capitals. Such trends were generally followed by each cluster of regions, distinguished by the characteristics of human capital (Tab. 3) and social capital (Tab. 4). The growth of human capital resulted from the improvement of indicators diagnosing knowledge

\footnotetext{
${ }^{6}$ The data for social capital is based on periodic panel studies "The Social Diagnosis", conducted every two years $(2003,2005,2007,2009,2011,2013,2015)$. For this reason, the analysis of the social capital in the regions referred to the period of 2003-2015.
} 
and competencies as well as the health of the inhabitants (only the indicators describing demographic processes deteriorated - the rate of natural increase, demographic dependency ratio). Changes in social capital were due to the improvement of those indicators describing citizenship and formal social networks. In line with theoretical prerequisites, the normative dimension turned out to be the least-susceptible to change.

Within an upward trend of human and social capital common to most regions in 2002-2014, significant changes occurred in those clusters of regions identified as similar because of the characteristics of the capitals in question. The composition of clusters was less stable than in the case of traditional factors of development (Tab. 2). This can be partly explained by the fact that, in 2002-2014, the level of regional disparities for human and social capital was lower than for the traditional economic factors; thus, even a small regional differentiation in the pace of change of human or social capital indicators could affect the regions' affiliation to their respective clusters (Tab. 2).

Nevertheless, the values of the variation coefficients based on the quartile deviation indicate that, in 2014, regional variations regarding human and social capital remained at a level similar as in 2002. In addition, when it comes to the structure of human capital, it can be seen that, in 2002-2014, regional differences in terms of education increased, and the regions have become more-and-more alike due to the health of their inhabitants. As for social capital, the largest interregional variations concerned the level of generalized trust, the relatively smallest ones being observed in the behavioral construct of this capital. For all components of social capital, the level of variations observed in 2015 was similar to those from 2003.

The analysis of variance sheds further light as to which variables had a statistically significant impact on determining the composition of the respective clusters. When it comes to human capital, that was the case for all of the elements shown in Table 3 except for the following: the rate of natural increase and (unexpectedly, perhaps) the proportion of people with tertiary-level educational attainment. As for social capital - almost all variables had a statistically significant impact on determining the composition of the respective clusters (the except was the active exercise of functions in organizations, and in 2003 also the activity on behalf of the local community).

In the clustering of regions by characteristics of human capital, a trend to merge the regions with very well-developed urban agglomerations and academic centers into a single cluster was increasingly noticeable in the subsequent years. In 2014, Mazovia (Warsaw), Wielkopolska (Poznan), Malopolska (Krakow), and Pomerania (Tri-city) regions were a part of Cluster No. 2, with the highest values of human capital indicators. With its high values of the variables of human capital, Cluster No. 1 was formed by Lower Silesia (Wroclaw), Silesia (Katowice), and West Pomerania (Szczecin). 


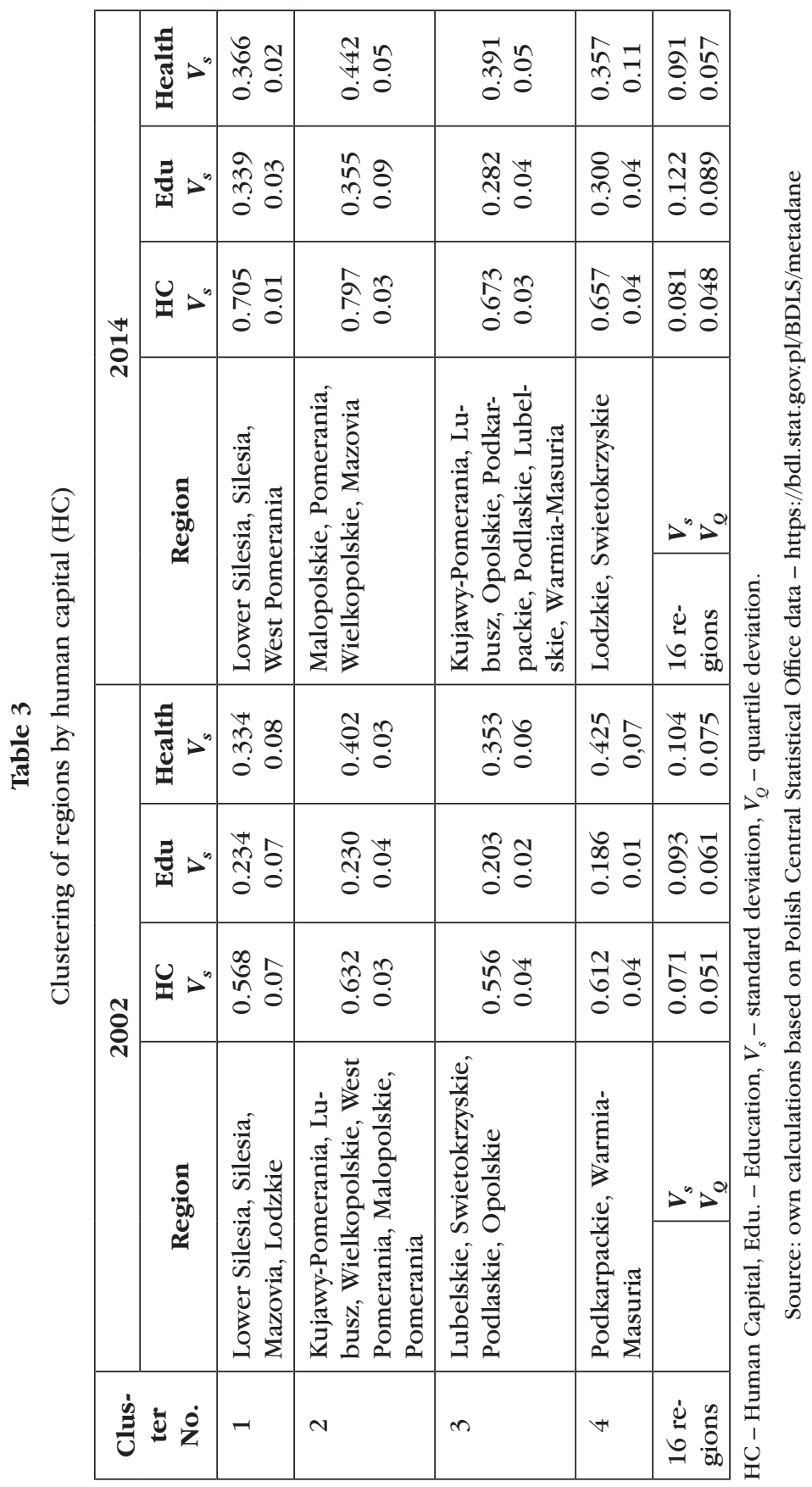


Table 4

Clustering of regions by social capital (SC)

\begin{tabular}{|c|c|c|c|c|c|c|}
\hline $\begin{array}{l}\text { Cluster } \\
\text { No. }\end{array}$ & \multicolumn{2}{|l|}{ Regions } & $\begin{array}{l}\mathrm{SC} \\
V_{s}\end{array}$ & $\begin{array}{c}\text { Trust } \\
V_{s}\end{array}$ & $\begin{array}{c}\text { Behav. } \\
V_{s}\end{array}$ & $\begin{array}{c}\text { Struct. } \\
V_{s}\end{array}$ \\
\hline \multicolumn{7}{|c|}{2003} \\
\hline 1 & \multicolumn{2}{|l|}{$\begin{array}{l}\text { Lower Silesia, Mazovia, Swietokrzyskie, } \\
\text { Pomerania }\end{array}$} & $\begin{array}{c}0.551 \\
0.02\end{array}$ & $\begin{array}{c}0.057 \\
0.16\end{array}$ & $\begin{array}{l}0.266 \\
0.03\end{array}$ & $\begin{array}{c}0.229 \\
0.08\end{array}$ \\
\hline 2 & \multicolumn{2}{|l|}{$\begin{array}{l}\text { Kujawy-Pomerania, Opolskie, Lubelskie, } \\
\text { Lubusz, Malopolskie }\end{array}$} & $\begin{array}{c}0.516 \\
0.04\end{array}$ & $\begin{array}{c}0.038 \\
0.17\end{array}$ & $\begin{array}{c}0.274 \\
0.04\end{array}$ & $\begin{array}{c}0.203 \\
0.08\end{array}$ \\
\hline 3 & \multicolumn{2}{|l|}{ Lodzkie, Silesia, West Pomerania } & $\begin{array}{c}0.481 \\
0.07\end{array}$ & $\begin{array}{c}0.043 \\
0.12\end{array}$ & $\begin{array}{c}0.228 \\
0.10\end{array}$ & $\begin{array}{c}0.210 \\
0.04\end{array}$ \\
\hline 4 & \multicolumn{2}{|l|}{ Podkarpackie, Podlaskie, Wielkopolskie } & $\begin{array}{c}0.518 \\
0.04\end{array}$ & $\begin{array}{c}0.056 \\
0.01\end{array}$ & $\begin{array}{c}0.260 \\
0.03\end{array}$ & $\begin{array}{c}0.202 \\
0.11\end{array}$ \\
\hline 5 & \multicolumn{2}{|l|}{ Warmia-Masuria } & 0.443 & 0.067 & 0.215 & 0.161 \\
\hline \multicolumn{2}{|c|}{16 regions } & $\begin{array}{l}V_{s} \\
V_{Q}\end{array}$ & $\begin{array}{l}0.071 \\
0.045\end{array}$ & $\begin{array}{l}0.228 \\
0.165\end{array}$ & $\begin{array}{l}0.089 \\
0.028\end{array}$ & $\begin{array}{l}0.107 \\
0.073\end{array}$ \\
\hline \multicolumn{7}{|c|}{2015} \\
\hline 1 & \multicolumn{2}{|l|}{$\begin{array}{l}\text { Lower Silesia, Lubelskie, Lubusz, } \\
\text { Opolskie }\end{array}$} & $\begin{array}{c}0.682 \\
0.03\end{array}$ & $\begin{array}{c}0.052 \\
0.11\end{array}$ & $\begin{array}{c}0.345 \\
0.03\end{array}$ & $\begin{array}{c}0.284 \\
0.06\end{array}$ \\
\hline 2 & \multicolumn{2}{|l|}{$\begin{array}{l}\text { Kujawy-Pomerania, Mazovia, } \\
\text { Swietokrzyskie }\end{array}$} & $\begin{array}{c}0.649 \\
0.05\end{array}$ & $\begin{array}{c}0.085 \\
0.03\end{array}$ & $\begin{array}{c}0.320 \\
0.06\end{array}$ & $\begin{array}{c}0.244 \\
0.05\end{array}$ \\
\hline 3 & \multicolumn{2}{|l|}{ Podkarpackie, West Pomerania } & $\begin{array}{c}0.619 \\
0.03\end{array}$ & $\begin{array}{c}0.062 \\
0.04\end{array}$ & $\begin{array}{c}0.326 \\
0.05\end{array}$ & $\begin{array}{c}0.231 \\
0.03\end{array}$ \\
\hline 4 & \multicolumn{2}{|l|}{$\begin{array}{l}\text { Lodzkie, Malopolskie, Wielkopolskie, } \\
\text { Pomerania, Silesia, Podlaskie }\end{array}$} & $\begin{array}{c}0.636 \\
0.05\end{array}$ & $\begin{array}{c}0.058 \\
0.20\end{array}$ & $\begin{array}{c}0.314 \\
0.05\end{array}$ & $\begin{array}{c}0.264 \\
0.06\end{array}$ \\
\hline 5 & \multicolumn{2}{|l|}{ Warmia-Masuria } & 0.608 & 0.125 & 0.278 & 0.206 \\
\hline \multicolumn{2}{|c|}{16 regions } & $\begin{array}{l}V_{s} \\
V_{Q}\end{array}$ & $\begin{array}{l}0.052 \\
0.045\end{array}$ & $\begin{array}{l}0.313 \\
0.170\end{array}$ & $\begin{array}{l}0.067 \\
0.032\end{array}$ & $\begin{array}{l}0.102 \\
0.074\end{array}$ \\
\hline
\end{tabular}

SC - Social Capital; Behav. - Behavioral (active citizenship); Struct. - Structural (formal networks); $V_{s}$ - standard deviation; $V_{Q}$ - quartile deviation

$$
\text { Source: own calculation }
$$

It is much more difficult to identify a trend for the grouping of regions by social capital. In this cross-sectional analysis, the distinctness of Warmia-Masuria can clearly be seen, showing a higher level of general social trust and significantly lower indicators of active citizenship and the functioning of social networks 
(when compared to the other regions). The resulting division of regions into those with higher and lower social capital is largely consistent with the one presented in "The Social Diagnosis" (2003-2015). The biggest discrepancies concerned the Podkarpackie and Kujawy-Pomerania regions (in "The Social Diagnosis", Podkarpackie was ranked among the regions that were best-equipped with social capital, and Kujawy-Pomerania was placed among the regions that were below average values for Poland). However, according to sociologists, the dividing line for social capital runs cross-sectionally: East-West and village-city (an agrarian-modern society versus a modern-postmodern one) (Cierniak-Szóstak 2012; Gorzelak, Jałowiecki 2010).

Comparing the grouping of regions by human capital and social capital, it is hard to see similarities between the two combinations. There is no basis to conclude that regions with a higher human capital form clusters with higher social capital nor that lower human capital coexists with a lower social capital; such correlations are visible when comparing European countries (Wosiek 2016) or at an individual level (Czapiński, Panek, 2013, p. 269-280).

However, certain similarities can be seen between the clusters distinguished for their human capital or for their traditional factors of development. They consist in the fact that the regions belonging to Clusters No. 1 and 2, with a relatively high GDP per capita, were at the same time in the set of regions with a relatively high human capital. The regions with relatively lower human capital showed an average or relatively lower saturation with traditional development factors. Such similarity cannot be seen between the grouping of regions by social capital and traditional development factors. In the group of regions with a high social capital, there were regions with both high GDP per capita (Mazovia) and low (Swietokrzyskie). This would indicate that the processes of regional development from 2002 through 2015 were linked to human capital to a greater extent and to social capital to a lesser one.

The question arises as to what extent human capital was a factor or a result of the economic development. The conducted grouping shows that high human capital was not a sufficient factor to achieve a high level of income - a set of areas with high human capital (Clusters No. 1 and 2) was formed by the regions with diversified GDP per capita. On the other hand, in the group of regions with a higher GDP per capita, there were only those with a higher human capital. This would suggest that the impulses running in the direction of "level of GDP per capita to human capital" prevailed in the correlation between human capital and economic development. Moving on to the next stage of development, the economy reported increasingly higher requirements for human capital, thus stimulating its changes. 
These findings are confirmed by the results of the correlation analysis (Tab. 5):

- human and social capital were more-largely-related to the level of GDP per capita than to the stimulation of its change (rate of growth). Human capital showed a greater impact on GDP per capita and its growth rate than social capital. However, there is a stimulating impact of human capital (a higher proportion of people with a tertiary level of educational attainment) and social capital (a positive attitude towards democracy) on economic growth when the threshold of statistical significance is set at $10 \%$;

- higher evaluation ratings of human capital coexisted with higher GDP per capita, and links with the component describing the knowledge and expertise were stronger than those with the health of the inhabitants;

- coexistence of a high GDP per capita and high ratings for social capital was observed for the index describing the attitude towards democracy, and for an active participation in associations. A poor performance of public administration institutions turned out to be an inhibitor. The level of generalized trust fostered a higher GDP per capita (but with a significance level of $10 \%$ ).

Table 5

Correlation between indicators of human/social capital and level/average growth rate of GDP per capita in 2002-2014

\begin{tabular}{|c|c|c|c|c|c|c|c|c|}
\hline \multirow{2}{*}{ GDP } & \multicolumn{8}{|c|}{ Human capital } \\
\hline & $\mathbf{h c}_{1}$ & $\mathbf{h c}_{2}$ & $\mathbf{h c}_{3}$ & $\mathbf{h c}_{4}$ & $\mathbf{h c}_{5}$ & $\mathbf{h c}_{6}$ & & $c_{7}$ \\
\hline \multirow{2}{*}{$\begin{array}{l}\text { GDP per } \\
\text { capita }\end{array}$} & 0.699 & -0.718 & 0.670 & 0.007 & 0.297 & 0.299 & \multicolumn{2}{|c|}{-0.337} \\
\hline & $(0.00)$ & $(0.00)$ & $(0.00)$ & $(0.919)$ & $(0.00)$ & $(0.00)$ & \multicolumn{2}{|c|}{$(0.00)$} \\
\hline \multirow{2}{*}{$\begin{array}{l}\text { GDP per } \\
\text { capita } \\
\text { growth } \\
\text { rate }\end{array}$} & 0.446 & 0.2501 & 0.074 & -0.361 & -0.305 & -0.008 & \multicolumn{2}{|c|}{-0.048} \\
\hline & $(0.084)$ & $(0.35)$ & $(0.786)$ & $(0.170)$ & $(0.251)$ & $(0.978)$ & \multicolumn{2}{|c|}{$(0.861)$} \\
\hline \multirow{2}{*}{ GDP } & \multicolumn{8}{|c|}{ Social capital } \\
\hline & $\mathbf{s c}_{1}$ & $\mathbf{s c}_{2}$ & $\mathbf{s c}_{3}$ & $\mathbf{s c}_{4}$ & $\mathrm{sc}_{5}$ & $\mathrm{sc}_{6}$ & $\mathbf{s c}_{7}$ & $\mathrm{sc}_{8}$ \\
\hline \multirow{2}{*}{$\begin{array}{l}\text { GDP per } \\
\text { capita }\end{array}$} & 0.116 & 0.002 & -0.007 & 0.434 & 0.096 & 0.179 & -0.265 & -0.128 \\
\hline & $(0.096)$ & $(0.980)$ & $(0.926)$ & $(0.00)$ & $(0.167)$ & $(0.010)$ & $(0.00)$ & $(0.066)$ \\
\hline \multirow{2}{*}{$\begin{array}{l}\text { GDP per } \\
\text { capita } \\
\text { growth } \\
\text { rate }\end{array}$} & 0.287 & 0.123 & 0.126 & 0.432 & 0.299 & 0.363 & -0.145 & 0.2989 \\
\hline & $(0.281)$ & $(0.649)$ & $(0.642)$ & $(0.095)$ & $(0.261)$ & $(0.167)$ & $(0.592)$ & $(0.261)$ \\
\hline
\end{tabular}

p-value in brackets.

Descriptions for $\mathrm{hc}_{1}, \mathrm{hc}_{2}, \mathrm{hc}_{3}, \mathrm{hc}_{4}, \mathrm{hc}_{5}, \mathrm{hc}_{6}, \mathrm{hc}_{7}$ and $\mathrm{sc}_{1}, \mathrm{sc}_{2}, \mathrm{sc}_{3}, \mathrm{sc}_{4}, \mathrm{sc}_{5}, \mathrm{sc}_{6}, \mathrm{sc}_{7}, \mathrm{sc}_{8}-\mathrm{see}$ Table 1 .

Source: own calculations 


\section{Conclusions}

Based on the studies conducted, several conclusions can be made:

1. In 2002-2014, the similarities among the regions in terms of human capital did not coincide with those distinctive of social capital. This may indicate an insufficient cohesion in the development of these two forms of capital in the Polish regional space. This would also suggest that these two forms of capital were substitutable to each other rather than complementary, making it difficult to effectively use the potential of the local human and social capital to stimulate development processes. The rule of substitution of social capital with human capital - resourcefulness and entrepreneurship of the inhabitants - is valid for the entire country of Poland. Nevertheless, the scope of this substitutability varies in respective regions and is conditioned by their presenting both forms of capital.

2. There are certain similarities between the clustering of regions by traditional factors of economic development and by the characteristics of human capital, but there was no major compatibility between the division of regions by social capital and their being equipped with classic productive factors. The results of the correlation analysis confirmed a stronger link of the processes of economic development in regions with human capital than in those with social capital, whereby there is evidence indicating that it was rather a higher level of economic development that stimulated changes in human capital ("suction" effect for qualified personnel) and the reverse impact of human capital on the change in GDP per capita was weaker.

3. There were no converging trends in human and social capital development in regional systems. Moreover, when it comes to the educational component of human capital (most-strongly associated with the level and changes in GDP per capita), there was an increase in regional variations during the analyzed period and a trend for those regions with very well-developed urban agglomerations and academic centers to merge into a single cluster was noticeable. It can be assumed that this component of human capital could have had more of a polarizing impact than a converging one. The activation of this trend might have been impacted by the conditions created for the functioning of human capital - greater complementarity with the physical capital in connection with more-advanced regional structures of production. The social capital did not mitigate nor strengthen the polarizing impact of human capital. Therefore, there was no confirmation to the hypothesis that intangible factors - human and social capitals - contributed to the convergence in living standards among regions in Poland in 2002-2014. 


\section{References}

[1] Bal-Domańska, B. (2014) 'Próba identyfikacji większych skupisk regionalnych oraz ich konwergencja,' Prace Naukowe Uniwersytetu Ekonomicznego we Wroctawiu, No. 327, pp. 285-293.

[2] Barro, R.J. (1992) 'Human capital and economic growth,' in Policies for long-run economic growth, A symposium sponsored by the Federal Reserve Bank of Kansas City, Jackson Hole, Wyoming, August 27-29.

[3] Barro, R.J. (1996) 'Determinants of economic growth: a cross-country empirical study,' NBER Working Papers, No. 5698.

[4] Becker, G.S. (1975), Human capital: a theoretical and empirical analysis, with special reference to education, University of Chicago Press, Chicago.

[5] Cierniak-Szóstak, E. (2012), 'Instytucjonalne uwarunkowania spójności społeczno-ekonomicznej’ in Woźniak, M.G. (ed.) Gospodarka Polski 1990-2011. Transformacja. Modernizacja. Spójność społeczno-ekonomiczna. Tom 3. Droga do spójności społeczno-ekonomicznej, Warszawa: PWN.

[6] Coleman, J.S. (1990) Foundations of Social Theory, Cambridge: Harvard University Press.

[7] Czapiński, J. (2008) 'Kapitał ludzki i kapitał społeczny a dobrobyt materialny. Polski paradoks,' Zarzadzanie Publiczne No. 2(4), pp. 5-28

[8] Czapińki, J. and Panek, T. (eds.) (2003-2015) Social Diagnosis 2003-2013: the objective and subjective quality of life in Poland, [Online], Available: www.diagnoza.com [16 Feb 2017].

[9] Dańska-Borsiak, B. (2011) Dynamiczne modele panelowe w badaniach ekonomicznych, Łódź: Wydawnictwo Uniwersytetu Łódzkiego.

[10] Dinda, S. (2008) 'Social capital in the creation of human capital and economic growth: a productive consumption approach,' Journal of Socio-Economics, vol. 37, No. 5, pp. 2020-2033, [Online], Available: http://dx.doi.org/10.1016/j. socec.2007.06.014 [7 Nov 2014].

[11] Dinda, S. (2014) 'Inclusive growth through creation of human and social capital,' International Journal of Social Economics, vol. 41, iss. 10, pp. 878-895, [Online], Available: http://dx.doi.org/10.1108/IJSE-07-2013-0157 [7 Nov 2014].

[12] Domański, S.R. (1993) Kapitał ludzki i wzrost gospodarczy, Warszawa: PWN.

[13] Dowrick, S. (2003) 'Ideas and Education: Level of Growth Effect,' NBER Working Paper, No. 9709, Cambridge.

[14] Fukuyama, F. (1997) Zaufanie: kapitał społeczny a droga do dobrobytu, Warszawa-Wrocław: PWN.

[15] Gajewski, P. and Tokarski, T. (2004) 'Czy w Polsce występuje efekt konwergencji regionalnej?,' Studia Ekonomiczne INE PAN, No. 1-2(XL-XLI).

[16] Gorzelak, G. (2008) 'Fakty i mity rozwoju regionalnego,' Zarzadzanie Publiczne, No. 4(6). 
[17] Gorzelak, G. and Jałowiecki, B. (2010), 'Siły lokalne i regionalne' in Morawski W. (ed.) Modernizacja Polski. Struktury. Agencje. Instytucje, Warszawa: Wydawnictwa Akademickie i Profesjonalne.

[18] Jabłoński, Ł. (2012) Kapitał ludzki a konwergencja gospodarcza, Warszawa: Wydawnictwa CH Beck.

[19] Kaasa, A. and Parts, E. (2008) 'Human Capital and Social Capital as Interacting Factors of Economic Development: Evidence from Europe,' Working Paper IAREG WP2/04, University of Tartu, Tartu.

[20] Kliber, P. (2007) 'Ekonometryczna analiza konwergencji regionów metodami panelowymi,' Studia Regionalne i Lokalne, No. 1, pp. 74-87.

[21] Kliber, P. (2011) 'Kluby konwergencji w rozwoju gospodarczym regionów Polski,' Zeszyty Naukowe Uniwersytetu Ekonomicznego w Poznaniu, No. 176, Poznań, pp. 241-256.

[22] Kosmalski, R. (2016) 'Konwergencja gospodarcza w Polsce w ujęciu sektorowym,' Wiadomości Statystyczne, No. 2, pp. 47-61.

[23] Krugman, P. (1991) 'Increasing Returns and Economic Geography, Journal of Political Economy, vol. 99(3), pp. 483-499.

[24] Kusideł, E. (2013) Konwergencja gospodarcza w Polsce i jej znaczenie w osiąganiu celów polityki spójności, Łódź: Wydawnictwo Uniwersytetu Łódzkiego.

[25] Miguélez, E., Moreno, R. and Artís, M. (2009) 'Does Social and Human Capital Reinforce Each Other in the Creation of Knowledge? Evidence from Spanish Regions,' Working Paper IAREG WP5/10, Research Institute of Applied Economics, University of Barcelona, Barcelona.

[26] Młodak, A. (2006) Analiza taksonomiczna w statystyce regionalnej, Warszawa: Difin.

[27] Ortigueira, S. and Santos, M.S. (1997) 'On the speed of convergence in endogenous growth models,' American Economic Review, vol. 87, No. 3, pp. 383-399.

[28] Piazza-Georgi, B. (2002) 'The role of human and social capital in growth: extending our understanding,' Cambridge Journal of Economics, vol. 26(4), pp. 461-479, [Online], Available: https://doi.org/10.1093/cje/26.4.461 [30 Jan 2017].

[29] Pritchett, L. (1997) 'Divergence. Big time,' Journal of Economic Perspective, vol. 11, No. 3, pp. 3-17.

[30] Putnam, R.D. (1995) Demokracja w działaniu: tradycje obywatelskie we współczesnych Włoszech, Kraków: Instytut Wydawniczy „Znak”.

[31] Romer, P.M. (1986) 'Increasing Returns and Long-run Growth,' Journal of Political Economy, No. 94(5), pp. 1002-1037.

[32] Schuller, T. (2000) 'The Complementary Roles of Human and Social Capital,' paper prepared for the OECD for Symposium on The Contrribution of Human and Social Capital to Sustained Economic Growth and Well-Being, Human Development, Canada, Quebec, March. 
[33] Schultz, T.W. (1961) 'Investment in human capital,' American Economic Review, vol. 51, No. 1, pp. 1-17.

[34] Strahl, D. (ed.) (2006) Metody oceny rozwoju regionalnego, Wrocław: Wydawnictwo Akademii Ekonomicznej im. O. Langego we Wrocławiu.

[35] Wosiek, M. (2016) 'Komplementarna rola kapitału ludzkiego oraz społecznego w inteligentnym rozwoju gospodarczym,' Studia Ekonomiczne, Zeszyty Naukowe Uniwersytetu Ekonomicznego w Katowicach, No. 276, pp. 58-71.

[36] Wójcik, P. (2008) 'Dywergencja czy konwergencja: dynamika rozwoju polskich regionów,' Studia Regionalne i Lokalne, vol. 2, No. 32, pp. 41-60. 